\title{
A Probe into the Multi-cultural Characteristics of The Last of the Mohicans
}

\author{
Ning $\mathrm{Du}^{1}$ \\ ${ }^{1}$ Foreign Language Teaching Department, Inner Mongolia University for Nationalities, China \\ Correspondence: Ning Du, Foreign Language Teaching Department, Inner Mongolia University for Nationalities, \\ Tongliao, Inner Mongolia, China. Tel: 86-475-831-3010. E-mail: duning59@163.com
}

Received: December 18, 2012 Accepted: January 4, 2013 Online Published: January 17, 2013

doi:10.5539/ells.v3n1p25 URL: http://dx.doi.org/10.5539/ells.v3n1p25

The research of this thesis is sponsored by Inner Mongolia University for Nationalities

\begin{abstract}
Within James Fenimore Cooper's masterpiece The Last of the Mohicans, this thesis mainly analyzes its multi-cultural characteristics - its unique American style and the American Indian culture embodied in it. Cooper chooses the American style, the cultural realm of frontier, and creates an image of an American hero-Hawkeye, Natty Bumppo. Cooper's own writing style was formed by borrowing some traditional culture of the old continent. He gives an expression to his opinions on society, politics and culture using practical narrative. American Indian culture - totems, names, painting and language can also be found in the novel.
\end{abstract}

Keywords: writing style, American Indian language, Totem, naming culture

\section{Introduction}

James Fenimore Cooper was an important founder of American literature who earned many "first" statuses in American literary history: the first professional writer, the first writer to describe native subjects, the first "unique American novelist" and so on. He manifested the lively American style in his most famous magnum opus The Leatherstocking Tales that made him one of the inaugurators of American literature. Among his most famous works is the Romantic novel The Last of the Mohicans, often regarded as his masterpiece. Multi-cultural characteristics which embody Cooper's great sense of innovation in literature and the social and moral significance of his works are reflected utterly in The Last of the Mohicans. The multi-cultural characteristics specifically embodied in The Last of the Mohicans will be analyzed from two aspects.

\section{A Uniquely American Writing Style}

Uniquely American literature refers to new literature which shows the environment, the subjects, the customs and the characters of America instead of using a European background and subject in its contents, and forms its own writing style in literature form which has made a breakthrough to some degree compared to the traditional literature of the old continent. There was no American literature in the nineteenth century, said a chorus of British and European critics of the new nation. "Literature the Americans have none - no native literature ... It is all imported," the Rev. Sydney Smith pronounced in the Edinburgh Review. In 1820, Smith famously insulted American pride: "In the four quarters of the globe, who reads an American book?" American writers realized their primary task was to create the American mythology by using some new materials, so from the very beginning American literature has had a very strong sense of pioneering and multi-culturalism. Just as Americans try to expand their territory to the west, Americans also want to develop their own realm to destroy the superiority that the English always have in literature. As a pioneer of literature, James Fenimore Cooper did not use a European background to attract readers as Washington Irving did; instead he created his own purely American style of literature. In his novel, we can find real American figures, an American environment and an American subject which form "Cooper's style".

\subsection{Theme and Content of the American Style}

As a pioneer of literature, Cooper created some figures different from those of the old continent, described a new continent full of imagination and beauty, and renewed the current history, environment, economy and culture. In 
the The Last of the Mohicans, the most popular work of The Leatherstocking Tales, Cooper still has Natty Bumppo as the principal character and the frontier period of American history as the background. The story takes place in 1757, during the French and Indian War (the Seven Years' War), when France and Great Britain battled for control of the North American colonies. During this war, the French called on allied Native American tribes to fight against the more numerous British colonists in this region.

\subsubsection{American Historical Background}

The history of America's founding and development is the process of Westward Movement. The west portrayed by Cooper is not only a geographical concept, but also a cultural concept; it represents the conflict between civilization and barbarism, law and nature. For the first time, Cooper used the vast expanse of the west as the backdrop of the story to display a vivid picture of life in the west. There is the tough life of the early settlers, the bloody battle between the colonialists, and the miserable bloody history of the Indians' westward movement. In The Last of the Mohicans, Copper intersperses a love story, but that is not the author's intention apparently - on the contrary, he pays much attention to the tragic consequences caused by war. At the beginning of The Last of the Mohicans, Cooper introduces the setting of the story: "It was in this scene of strife and bloodshed that the incidents we shall attempt to relate occurred, during the third year of the war which England and France last waged for the possession of a country that neither was destined to retain." (Cooper, 1826, p. 5) The story takes place during the Seven Years' War. This conflict, which lasted from 1756 to 1763, involved all of the major European powers of the period. It resulted in some 900,000 to 1,400,000 deaths and significant changes in the balance of power and territories of several of the participants. Also known as the French and Indian War, the conflict occurred between British settlers and colonial forces, and royal French forces together with the various Native American forces allied with them. The fate of the Mohicans is a miniature of the fate of all American Indians during the colonization of north America; the history of civilization in North America is a history of diminishing and even extinguishing the American Indians.

\subsubsection{Individualism in the American Western Novel}

Individualism is the core of American culture. It focuses on the satisfaction of one's own desires and interests through self-reliance. There is a very important and close relationship between American individualism and the Western novel. Both of them are connected with each other by the word hero in this thesis. Namely, the image of a hero in the American Western novel is created by the American value of individualism. In The Last of the Mohicans, Cooper pioneered the image of a hero in the American Western novel. Natty Bumppo, an idealized heroic character with some new American characteristics and some excellent qualities of American nationality, who, separated from both traditional and white societies, embodies only the best qualities of both cultures. How far from the pastoral ideal is the character described by D. H. Lawrence as "A man who turns his back on white society, a man who keeps his moral integrity hard and intact, an isolate, almost selfless, stoic, and enduring man, who lives by death, by killing, but who is pure white." The spirit exemplified in this hero was followed by many American writers: Herman Melville's Budd, Mark Twain's Huckleberry Finn, Hemingway's Santiago, and even the dog Buck created by Jack London. In all these characters we can find a common feature: the pursuit for freedom, fulfilled in an isolate way, which exemplifies their intense individualism.

\subsection{Writing Characteristics of the American Style}

Cooper's whole novel, just as the American nation, is full of the pioneer's spirit, which is respectable. His achievements in writing seem pale beside his contribution to the development of a new realm in theme for American literature.

\subsubsection{A Pragmatic Language System}

Cooper spent a lot of time studying the art of language expression, especially in English literature. As a writer with intense national self-awareness, he tried his utmost to create his novel by exemplifying the American theme, meanwhile seeking a new way to express himself in his works. Cooper combined his creation with traditional English literature, from which came Cooper's own characteristic style - reinventing the literature tradition of the old continent. After reading The Last of the Mohicans, one can see how Cooper conveys his opinions using a pragmatic language system - he is good at it. Pragmatism is an expression of the American spirit. As theirs is a country full of immigrants, Americans must work hard and fight against nature to exist on the virgin land, so America cultivates the spirit of a quest for truth and for pioneering, which is the source of American pragmatism. The pragmatists rejected all forms of absolutism and insisted that all principles be regarded as working hypotheses that must bear fruit in lived experience. Americans seem more interested in getting things done and in the results of actions rather than abstract theories which do not inspire action. Pragmatism was used in daily life, science, politics and even literature. In The Last of the Mohicans, Cooper used the narrative of pragmatism 
realistically and effectively, which can be seen especially in the author's strong discourse power, namely via the author himself or the characters of the novel. His social and political ideas were woven into his works and were expressed in indubitable tune and tone to emphasize the correctness of his opinion, which made his work have an intense sense of authority. The very fact of this direct and pragmatic discourse manner led the readers into the trap of strong discourse power unconsciously.

\subsubsection{Use of Native American Language}

While Cooper did his utmost to create the setting, figures and environment with American characteristics, he also tried to consider the language to be used in his work. Undoubtedly the residents of the new continent communicated with each other in English, but Cooper wanted to make some differences on this point, so the native languages of American Indians were used in his work. Although for the understanding of the readers Cooper translated the native languages in his work, we can still feel the mysterious power of the native languages. At that time, native dialects of American Indians were regarded as a kind of "subculture" which was barbarous and primitive to European immigrants. But from Cooper's point of view, if he wanted to make a breakthrough in the form of traditional European literature, the native language of American Indians was the best way to rebel. Later, the prosperity of dialect literature in American literary history seemed to prove the brilliance of Cooper's idea.

American Indians live in the natural environment, so flowers, grasses, trees, fish, birds, etc. from nature become important carriers of their language. Another significant feature of Indians' native languages is that they are fond of acquiring the metaphors originated from nature to express their thoughts vividly and perfectly. For example, "Would you set a cloud to chase the wind?" (Cooper, 1826, p. 28) "If you would save these tender blossoms from the fangs of the worst of serpents...Then follow, for we are losing moments that are as precious as the heart's blood to a stricken deer!" (Cooper, 1826, p. 29) From these sentences we can see that Indians draw their metaphors from the clouds, the seasons, the birds, the beasts, and the vegetable world. In this, perhaps, the North American Indian clothes his ideas in a dress that is different from that of the African, and is oriental in itself. Cooper's language has the richness and sententious fullness of the Chinese language. He expresses a phrase in a word, and he qualifies the meaning of an entire sentence by a syllable; he even can convey different significations by the simplest inflections of the voice. What's more, the use of personal pronouns is different when Indians are talking. Where we feel the first person or the second person must be used, they like to use a nickname, name or the third person, which can be found clearly in Cooper's novels. For example: "Uncas is here," said another voice, in the same soft, guttural tones, near his elbow; "who speaks to Uncas?" (Cooper, 1826, p. 19) The first person is supposed to be used, but here, the name belonging to the third person is used.

The 2009 edition of "SIL Ethnologue" lists 438 living languages for American Indians, of which 29 are spoken by at least one million people. Cooper was the first person to use Native American language in his work. Hawkeye, the white man, and Chingachgook and Uncas, the Indians, all master English and an Indian language. Compared with sentences made with normal grammar habits, the native languages' sentences are much simpler and purer, and can reflect figures naturally and exactly, because Indians' language is bold, picturesque, figurative and full of perceivable specific descriptions and impressions of things that originated from their primitive and lonely life. Cooper tried his utmost to keep the original features of the native Indians' languages by displaying the rhythmical hallmarks of the Indians' verbal language and also using nonverbal language while the Indians are talking. When Hawkeye is first introduced conversing with Chingachgook, no indication is given that he speaks in broken Delaware. Throughout the book, he engages with the father and son with ease. Hawkeye persuades only "by speaking the language as it should be spoken," opening himself to its spirit and therefore opening the Mohicans up to "the truth [he] expresses" (Cooper, 1826, p. 29). However, Cooper elsewhere focused upon the command exercised by an eloquent speaker in Native American cultures and he seems to understand that certain Native Americans possess this mastery more than others, whether by native skill or cultivation. Therefore, the fact that he presents the non-native speaker Hawkeye as not only fluent but ultimately masterful in Delaware oratory suggests that it is Hawkeye's superiority in the language that is being indicated, as well as the superiority of the language itself. The scene concludes as follows:

The latter was...fast losing ground, and the point was about to be decided against him, when he arose to his feet, and shaking off his apathy, he suddenly assumed the manner of an Indian, and adopted all the arts of native eloquence. Elevating an arm, he pointed out the track of the sun, repeating the gesture for every day that was necessary to accomplish their object..... Conviction gradually wrought its influence, and towards the close of Hawkeye's speech, his sentences were accompanied by the customary exclamation of commendation. In short, Uncas and his father became converts to his way of thinking, abandoning their own previously expressed opinions. (Cooper, 1826, p. 199) 
Hawkeye "converts" the Mohicans to his way of thinking and he does so, moreover, by displaying a superiority in logical reasoning. On the other hand, supporting evidence of Cooper's remarkable rule of linguistic mobility is given by the lower class Hawkeye's native fluency in Delaware.

As a pioneer of the American western novel, his historical romances of frontier and Indian life in the early American days created a unique form of American literature. Research of these novels created during the pioneer period of western settlement is the best approach to know American native culture and the country's historic development.

\section{Characteristics of American Indian Culture}

American Indian culture is still alive. There are millions of American Indians living today in every corner of North America, Latin America and the Caribbean. There are some very important values in American Indian culture, such as: respect for nature, an emphasis on social common sense, the relationship between human beings and the universe, the relationship between men and women, and the recognition of happiness and peace, etc. The Last of the Mohicans embodies Native American culture typically.

\subsection{Totem Culture}

There are two sentences in The Last of the Mohicans that embody totem culture: "We were one people, and we were happy. The salt lake gave us its fish, the wood its deer, and the air its birds. We took wives who bore us children; we worshipped the Great Spirit" (Cooper, 1826, p. 18). "The Hurons are boasters," said Uncas, scornfully; "their 'totem' is a moose, and they run like snails. The Delawares are children of the tortoise, and they outstrip the deer" (Cooper, 1826, p. 213). "We worshipped the Great Spirit" and "The Hurons' 'totem' is a moose; the Delawares' is tortoise." The word "totem" derives from an American Indian language, meaning "its relative" or "its mark". In the belief of the primitive, they thought the people from the same tribe originated from the same species, and in most cases, they had some relationship with certain animals. Thus, there is a connection between totem worship and the worship of ancestors. Among some totem mythologies, Indians believed that their ancestors came from or had some genetic relationship with a kind of animal or plant. In this way, the animal or plant would be the ancient ancestor of this tribe. Once a kind of plant or animal is seen as totem, it will be worshiped by all the members of the tribe. They cannot kill or hurt the totem, otherwise they will be punished. We can take this as a religious awareness at the primary stage in the development of human society. The biggest reason for Indians' worship of animals or plants is that they think animals or plants have their own souls, with unlimited ability and supernatural power for survival, existing before human beings, so they are superior to human beings who are only a pile of meat and bones. Only when humans choose a kind of animal to worship can they be helped or saved. And Indians regard the totem - the animal or the plant — as a symbol of a family or a tribe by painting it on their bodies, clothes or houses.

American Indians' beliefs are a complicated topic. Different tribes worship different spirits. In general, fishing tribes take the beaver, shark and whale as their totem; hunting tribes take the wolf, deer and bear as their totem.

\subsection{Naming Culture}

Another notable feature of the novel is that Cooper uses more than one name for many of the characters and groups of people. For example, "The battle was now entirely terminated, with the exception of the protracted struggle between 'Le Renard Subtil'and 'Le Gros Serpent.' Well did these barbarous warriors prove that they deserved those significant names, which had been bestowed for deeds in former wars" (Cooper, 1826, p. 84). The above paragraph concerns the naming culture of American Indians. "Le Renard Subtil" refers to the name given to the enemy chief of the Hurons, Magua, which means "the cunning fox", while "Le Gros Serpent" is the nickname for the chief of the Mohicans, Chingachgook, and "Le Cerf Agile" is Chingachgook's only son, Uncas. Nathaniel Bumppo refers to himself as Natty. The Mohicans call him Hawkeye, and the French and their Huron allies use the term La Longue Carabine (Long Rifle) for both Bumppo and his rifle, Killdeer.

All these names, especially the nicknames, reflect each figure's characteristics precisely, which is the very feature of Indians' names, namely, an Indian's name tells the world what he is - a coward, a liar, a thief, or a hero, just as the proverb says: "As his name is, so is he." Generally speaking, every Indian has at least three names during his lifetime. His first name is given to him at birth, which describes something that has happened at that time. For example, when a baby is born, the woman who is helping his mother goes down to the river to get some water with which to wash him. When she returns to the house, she remarks that she heard a wolf howling across the river. The baby's mother decides to name her son Howling-in-the-Middle-of-the-Night. Each Indian is supposed to keep his birth name until he is old enough to earn one for himself. But his playmates will always give him a name of their own. Often it is not flattering. Bow Legs, Crazy Dog, Crooked Nose or Wolf Tail are 
not good names. But sometimes a name fits so well that the youngster finds it difficult to shake it off. If he cannot earn a better one on the warpath later, he could be stuck with a name like Bow Legs for the rest of his life. The Indian earns his real name when he is old enough for his first fight against the enemy. His life name depends on how he acts during the first battle. When he returns from the warpath, the whole tribe will gather. They will witness the ceremony in which he will be given his tribal name by the chief. If he has done well, he will be given such a name as Five Killer, but if he has done poorly, he may be called Coward Woman. A man is given many chances to improve his name, however. At times, American Indians can give a man a name based on his behaviors or traits, such as Dances with Wolves or Wind in His Hair. So in The Last of the Mohicans the Indians' name for each character tells his record or describes his personality exactly and directly.

\subsection{Body-painting Culture}

"His body, which was nearly naked, presented a terrific emblem of death, drawn in intermingled colors of white and black. His closely-shaved head, on which no other hair than the well-known and chivalrous scalping tuft was preserved, was without ornament of any kind, with the exception of a solitary eagle's plume, that crossed his crown, and depended over the left shoulder.'(Cooper, 1826, p. 16)

"Quicker than the thoughts could follow those unexpected and audacious movements, an image, armed in the emblematic panoply of death, glided before their eyes, and assumed a threatening attitude at the other's side. "(Cooper, 1826, p. 84)

From the preceding sentences we can find something about Indians' material and spiritual culture in general, which reflects their religious beliefs and practices. Their customs, such as body painting, cutting or shaving hair, piercing lips and ears for the insertion of rings or other ornamental objects, adorning and covering the body with skins of animals, feathers of birds, or with necklaces, bracelets, and other ornaments, are all found in The Last of the Mohicans. The primitive ornaments are, in a large measure, used as "means of attraction" or as sexual stimulants. Professor Vonden Steinen, in his book on the Xingu tribes, discusses, among other things, the Indian custom of painting the body. He distinguishes between the practice of simply coating the body with paint and the practice of making real patterns and ornaments, and is of the opinion that only the latter owes its origin to aesthetic considerations. The former has arisen from purely practical motives. Thus the native coats himself with oil paint in order to preserve the skin against the influences of heat or to protect himself against mosquitoes and flies.

Before going out for a battle, American Indian warriors will be "armed in the emblematic panoply of death". In fact the panoply here is the body painting which symbolizes death in accordance with Indian customs. The facts are sufficient to permit a general conclusion as to the origin of body painting among American Indians. There are numerous instances, in which body painting cannot possibly be accounted for by any of the theories; neither can it be explained as an "ornament" in the common sense of the word, nor as a protection against mosquitoes and flies, or against the changes of the weather. Although such motives may have operated in exceptional cases, it seems evident that the custom of body painting has, above everything, been connected to the magical and religious beliefs of the natives - a fact that cannot surprise anybody who knows the predominant part religion and superstition plays in the practical life of the Indian. The fundamental idea underlying body-painting seems to be that it gives the body strength, and hence affords an efficacious protection against disease, witchcraft and evil influences in general.

\section{Conclusion}

To sum up, this thesis discusses the multi-cultural characteristic embodied in Cooper's masterpiece, The Last of the Mohicans, which chooses the cultural realm of the American frontier to record the hard life of the pioneers, the conflicts of the colonial period and the miserable situation of the Native Americans. Meanwhile, an image of an American hero, Hawkeye, or Natty Bumppo, is created to be an unattainable mythology pursued by Americans. In his writing, Cooper forms his own unique style while borrowing from the traditional literature of the old world. For one thing, he expresses his social, political and cultural notions using a pragmatic language system. For another, in the interest of highlighting the features of Native American language, Cooper displays a vivid multi-dimensional language world by means of a colorful representation of the Native American languages. When he describes Indian culture of the pioneer period, he integrates it with his reflection on the Westward Movement. In the novel, Cooper arouses growing public concern about American Indian suffering. Furthermore, Cooper appeals to all nations with a heterogeneous cultural background to live in harmony with one another by depicting the cruel war between England and France and the bloody battles between different American Indian tribes - a harmony, which human beings have been exploring consistently and seeking persistently. 


\section{References}

Allen, D. W. (1981). By All the Truth of Signs': James Fenimore Cooper's The Last of the Mohicans. Studies in American Fiction.

Bergmann, F. (1985). The Meaning of the Indians and Their Land in Cooper's The Last of the Mohicans. In Frank Bergmann (Ed), Upstate Literature; Essays in Memory of Thomas E. O'Donnell. Syracuse, NY: Syracuse University Press.

Chang, Y. X. (1996). A Survey of American Literature. Tianjin, China: Nankai University Press.

Cooper, J. F. (1986). The Last of the Mohicans. New York, NY: Viking Penguin.

Darnell, D. (1965). Uncas as Hero: The Ubi Sunt Formula in The Last of the Mohicans. American Literature (Vol. 37, pp. 259-266). Duke University Press. http://dx.doi.org/10.2307/2923258

Pearce, R. H. (1988). Savagism and Civilization: A Study of the Indian and the American Mind. University of California Press.

Spiller. R. E. (1955). The Cycle of American Literature: An Essay in Historical Criticism. New York, NY: The Macmillan Company.

Taylor, A. (1995). William Cooper's Town: Power and Persuasion on the Frontier of the Early American Republic. New York: A.A. Knopf.

Zhang, C. (2000). Literary History of the United States. Shanghai, China: Shanghai Foreign Language Education Press. 